\title{
Effectiveness of Supervision of Spatial Planning Policies in the Karangsambung Geological Preserve Area
}

\author{
Indraya Kusyuniadi $^{1, *}$, and Imam Buchori ${ }^{2}$ \\ ${ }^{1}$ Student of Master Degree, Master of Environmental Sciences, Diponegoro University, Semarang - Indonesia \\ ${ }^{2}$ Department of Regional and Urban Planning, Faculty of Engineering, Diponegoro University, Semarang - Indonesia
}

\begin{abstract}
The Karangsambung Geological Preserve area (KCAGK) is an area that has unique rocks and fossils, so it is nicknamed the "Black Box" process of the universe. Spatial policy in the form of a national, provincial and district Spatial Plan (RTRW) which establishes as a strategic area from the interests of environmental carrying capacity, as a consequence it is prohibited from all activities that change geological formation. Illegal mining activities are still a threat to the loss of protected rock diversity. The development of the industrial revolution era 4.0 has brought consequences and demands for increased accountability, transparency in public services by the government, thus bringing a paradigm shift and the role of supervision of spatial planning policies. This research will focus on aspects of supervision that are reviewed from the institutions and participation of the community. The study was carried out at the KCAGK location in Kebumen Regency, using quantitative methods through the information target was the community represented by village officials, community leaders and miners, while the institutions consisted of LIPI (Indonesian Institute of Science) and local government.
\end{abstract}

Keywords: RTRW Policy; Effectiveness; Supervision; Geological Preserve Area; Community; institutional

\section{Introduction}

Regional development is an embodiment in creating economic growth that has an impact on the welfare of society, but economic growth seems to be the main goal and heed the impact and sustainability. Conditions in the late $80 \mathrm{~s}$, where the environment had not been considered a priority in economic and social growth. These conditions changed in 1987 when the paper on the Brundtland report "Our shared future" and the emergence of the concept of sustainable development [1]. Development that can fulfill the current generation without reducing future generations is defined as sustainable development [2].

In realizing sustainable development, we are confronted with sectoral conflicts, namely: social, economic and environmental. The existence of social, economic and ecological sectoral interactions will lead to land-use conflicts in a particular location [3]. The environmental problem in sustainable development is triggered by economic interests that are considered a priority, so that material welfare is the main thing especially in favor of large investors. Whereas the environment is seen as a less important need so that it will lead to exploitative ways of utilizing existing natural resources.

The interests of the space each have sectoral goals, including: 1) Social interest, with the aim of improving quality of life, welfare and empowerment, 2) Economic interests, goals are growth, equity, economic stability, and efficiency and 3) Environmental interests, objectives carrying capacity and environmental capacity for nature conservation. The spatial planning policy in the form of a regional spatial plan is expected to become a reference, a direction for development, this is in accordance with Law Number 26 of 2007 concerning Spatial Planning.

The legal product of spatial planning is a policy set forth in the form of legislation nationally and regionally [4]. The understanding of the spatial plan in the implementation process is carried out continuously, meaning that the monitoring or evaluation process, evaluation and review of spatial plans are important in creating sustainable effectiveness and planning [5]. Today's environmental protection challenges in addition to fulfilling spatial planning policies require implementation that must synergize with technological advances, where almost all sectors are aware of the era of 4.0 which integrates physical, digital and biological conditions so that it will fundamentally change lifestyles and social interactions [6]. Karangsambung area, which is a meeting of the Indo-Australian plate with the Continent Asia plate, is an area that has been designated as a Geological Reserve Area. One of the provisions is through the National, Provincial and Kebumen Regional Spatial Planning policies. Areas that should be sterile from rock mining activities, but the reality in the field is often found in these activities. This condition will have

\footnotetext{
* Corresponding author: indraya kus@yahoo.co.id
} 
an impact on the reduction and even loss of geodiversity at KCAGK.

\subsection{Formulation of the problem}

In facing challenges in the industrial era 4.0 it is necessary to immediately address the existing pattern of change, while spatial planning policies still face many obstacles. In its mandate, the RTRW must protect KCAGK from geodiversity extinction, but it is still weak at the supervision stage, marked by the existence of rock and sand mining activities that can change geological formation and damage the environment.

\subsection{Research question}

What factors have caused the effectiveness of the RTRW policy supervision to be seen from the institutional aspects and community involvement in Geological Preserve Area?

\subsection{Goal research}

Identifying the effectiveness of institutional roles and the risks involved in overseeing the RTRW policy in Geological Preserve Area.

\subsection{Hypothesis (optional)}

There are factors that cause the oversight aspect of the RTRW at KCAGK to be weak, in terms of the institution and role of the community. Institutional aspects have a significant relationship to 1) task authority, 2) coordination between institutions, 3) funding and 4) human resources. Whereas from the role of the community are: 1) ignorance of the RTRW policy, 2) lack of socialization, 3) environmental indifference and 4) lack of place in supervision involvement.

\section{Literature Review}

\subsection{Spatial plan based on environmental carrying capacity}

Spatial planning based on environmental sustainability is an effort to realize a balance of natural resources and a sustainable environment [7]. Whereas the understanding of the carrying capacity of the environment is the ability of the environment to support the lives of humans and other living beings and the balance between the two.

\subsection{The implementation of Spatial Planning}

The implementation of Spatial Planning basically includes 4 (four) important contents, among them: 1) Arrangement of Spatial Planning, 2) Development of Spatial Planning, 3) Spatial Planning Implementation and 4) Spatial Planning Supervision. The following is the process of organizing spatial planning in each process.

\subsection{Monitoring spatial plans in maintaining sustainability}

Monitoring regional spatial plans has been considered as an increasingly important factor in the implementation of the learning plan and process, besides monitoring spatial plans is fundamental in the planning process, useful in whether the plans are in line with objectives and ensuring sustainable development [8].

\subsection{Geopark concept as protection against KCAG}

The definition of Geological Reserve Area is part of a geological protected area that has unique rocks, fossils, and landscapes. The uniqueness of rocks and fossils functions for natural laboratories, past life traces, anthropological and archaeological values and historical traces of geological structures [9].

The concept of geopark is an integrated unity that will 1) conservation, 2) education and 3) sustainable development, while this concept is considered an approach in promoting geological conservation according to McKeever [10]. Three main aspects of supporting the concept of Geopark include: 1) conservation of rock heritage, 2) economic development, and 3 ) community participation [11].

\subsection{Effectiveness of Policy Supervision}

Understanding effectiveness is a measure that states the achievement of targets in quantity, quality and time, a high level of effectiveness is indicated by the large percentage of targets achieved according to Hidayat in [12]. In other words, effectiveness is the achievement of a target or goal by carrying out the right and appropriate actions. While the elements of the effectiveness criteria consist of accuracy: 1) time, 2) cost calculation, 3) measurement, 4) making choices, 5) thinking, 6) making orders, 7) setting goals and 8) goals [13].

Supervision is a systematic activity including setting standards, comparing real conditions with standards, determining and measuring deviations that occur and corrective actions. Artiya has a link between planning and supervision, so planning is a guideline for monitoring [14].

\subsection{The role of industry 4.0 in public services}

Another term for industry 4.0 is the digital revolution, the fundamental thing in digital mention is the occurrence of a computer revolution in all fields. These conditions make the world movement of the labor competition industry not monotonous or linear. Substitution of human power with robots causes cheaper, more effective, efficient.

\section{Method}

By using quantitative methods, this study chose descriptive study techniques. By trying to get 
information in a descriptive and complete manner in a certain condition and situation according to Boyd, et al 1989 in [14].

\subsection{Research variable}

The research variables taken are 1) Still not optimal function and implementation of institutions in supervision, 2) Lack of community involvement. The following is a schematic variable that affects the effectiveness of monitoring spatial policy in protected areas. While the intervening variables include culture, costs and IT (Table 1).

Table 1. Research Variables

\begin{tabular}{|c|c|c|}
\hline $\begin{array}{l}\text { Independent } \\
\text { Variable }\end{array}$ & & $\begin{array}{c}\text { Dependent } \\
\text { Variable }\end{array}$ \\
\hline Institutional & & \multirow{2}{*}{$\begin{array}{l}\text { Effectiveness } \\
\text { of supervision }\end{array}$} \\
\hline \multirow[t]{3}{*}{$\begin{array}{l}\text { The role of the } \\
\text { community }\end{array}$} & & \\
\hline & Intervening Variable & \\
\hline & $\begin{array}{l}\text { - Community culture } \\
\text { in environmental } \\
\text { protection } \\
\text { - Cost } \\
\text { - IT (era 4.0) }\end{array}$ & \\
\hline
\end{tabular}

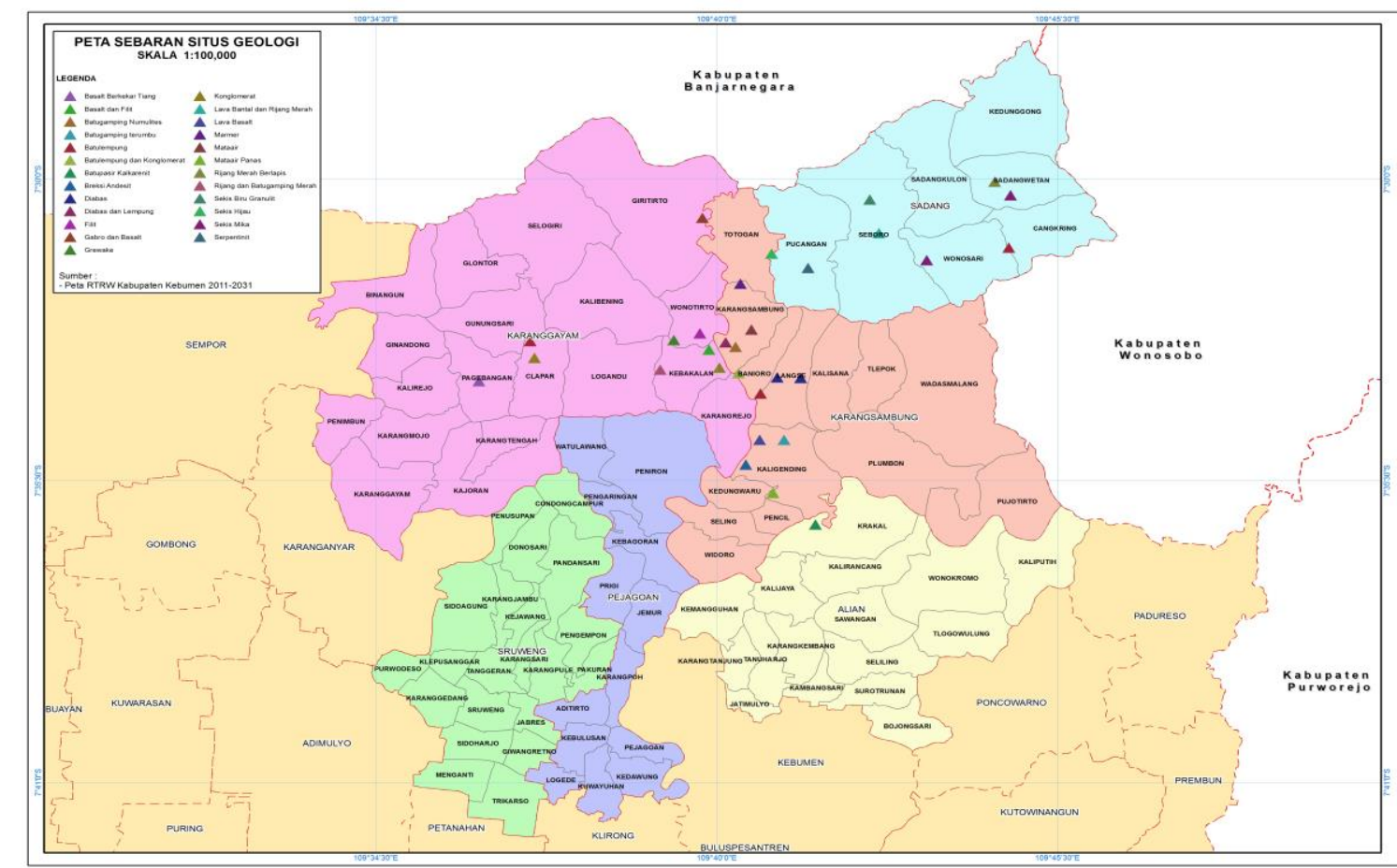

Source: RTRW Kebumen Regency

Fig. 1. Location of KCAGK in Kebumen Regency

\subsection{Research Indicator}

The classification of variables and indicators in this study selected 2 (two) variables to be examined, namely in the form of.

Table 2. Research Indicator

\begin{tabular}{|l|l|}
\hline $\begin{array}{c}\text { Variable } \\
\text { classification }\end{array}$ & \multicolumn{1}{c|}{ Indicator } \\
\hline $\begin{array}{l}\text { Institutional } \\
\text { Supervision }\end{array}$ & $\begin{array}{l}\text { 1. Role of external institutions (LIPI) } \\
\text { 2. The role of internal institutions, in this } \\
\text { case, the Regional Spatial Planning } \\
\text { Coordinating Board (BKPRD) }\end{array}$ \\
\hline $\begin{array}{l}\text { Community } \\
\text { involvement }\end{array}$ & $\begin{array}{l}\text { 1. The role of the community in delivering } \\
\text { environmental information } \\
\text { 2. Community involvement in activities } \\
\text { supporting the environment }\end{array}$ \\
\hline
\end{tabular}

\section{Results And Discussion}

\subsection{KCAGK Location Description}

The Karangsambung Geological Reserve area in Kebumen Regency is located in 6 (six) sub-districts, namely: Karanggayam, Alian, Sadang, Karangsambung, Sruweng and Pejagoan. It has a land area of $\pm 22,154$ Ha, with Desa Karangsambung in the center of the area. While the distance of the area to the urban center of Kebumen is $\pm 19 \mathrm{~km}$. Geographically, the area is located in the north of the administrative district of Kebumen, which has the characteristics of valleys and hills as part of the Southern Serayu Mountains. The following is a map of the Karangsambung Geological Reserve Area in Kebumen Regency. 


\subsection{Spatial planning policy at KCAGK}

In 2008, based on the RTRWN (National Regional Spatial Planning) through PP (Government Regulation) No. 26 of 2008 stipulated a geological protected area as one of the national protected areas. Next in 2010 through the RTRW (Regional Spatial Plan) of Central Java Province with Regional Regulation No. 6 of 2010 reaffirmed the Karangsambung Geological Reserve Area. Lastly in 2012 through the RTRW (Regional Spatial Planning) of Kebumen Regency through Regional Regulation Number 23 of 2012.

\subsection{The content of the RTRW to KCAGK}

Regency RTRW is a strategic area according to environmental protection. In the general provisions of zoning regulations, states that the Karangsambung Geological Reserve protected area is prepared with the following provisions: 1) prohibited from carrying out activities that change certain geological forms that have benefits for the development of science, protection of flora and fauna, and water conservation; and 2) pay attention to the requirements for building establishment that support educational, research and tourism activities. Also in the content of the district RTRW also regulates: 1) Provisions for Licensing, 2) Provisions for Providing Incentives and Disincentives, 3) Community Participation and 4) Institutional.

\subsection{Results}

\subsubsection{The Role of the Community in Supervision}

Understanding of the RTRW policy, almost the majority did not know, only about $25 \%$ knew, but all respondents knew of KCAGK at their location. Lack of socialization was also felt by respondents, so most (76\%) answered that socialization was not effective.

Table 3. Understanding and socialization of the RTRW

\begin{tabular}{|l|l|l|r|}
\hline \multicolumn{3}{|l|}{ Understanding and socialization of the RTRW } \\
\hline 1.A & \multicolumn{4}{|l|}{ Understand/be aware of the RTRW } \\
\hline & A & Understand/know & $25.0 \%$ \\
\hline & B & Do not know & $75.0 \%$ \\
\hline 1B & \multicolumn{4}{|l|}{ Knowing the existence of KCAGK } \\
\hline & A & Knowing & $100.0 \%$ \\
\hline & B & Do not know \\
\hline 1C & Is there socialization? & $16.0 \%$ \\
\hline & A & There is & $84.0 \%$ \\
\hline & B & There is no & $4.0 \%$ \\
\hline 1D & Has Effective Socialization Already? \\
\hline & A & It's effective & $20.0 \%$ \\
\hline & B & not so effective & $76.0 \%$ \\
\hline & C & Not yet / not
\end{tabular}

On the indicators of mining licensing, the average answer is a difficult process (34\%) and understands if there is no permission given for mining at KCAGK $(30 \%)$.
Table 4. Mining licensing

\begin{tabular}{|l|l|l|r|}
\hline \multicolumn{3}{|l|}{ Mining licensing } & \\
\hline 2A & \multicolumn{2}{|l|}{ What about existing licenses? } & $34.6 \%$ \\
\hline & a & No Easy / Difficult & $11.5 \%$ \\
\hline & b & Easy & $23.1 \%$ \\
\hline & c & Do not know & $30.8 \%$ \\
\hline & d & There is no permission & \\
\hline 2B & \multicolumn{2}{|l|}{ Why are miners not licensed? } & $22.6 \%$ \\
\hline & a & There is no budget & $38.7 \%$ \\
\hline & b & Worry is not allowed & $16.1 \%$ \\
\hline & c & Difficult process & $22.6 \%$ \\
\hline & d & Do not know & \\
\hline 2C & Is it effective? & $0.0 \%$ \\
\hline & a & yes it's effective & $0.0 \%$ \\
\hline & b & not so effective & $76.0 \%$ \\
\hline & c & Not yet / not & $24.0 \%$ \\
\hline & d & Do not know & \\
\hline
\end{tabular}

As for intensive and disintensive provision, the whole is deemed necessary, but has not been implemented so far.

Table 5. Intensive and Disintensive Implementation

\begin{tabular}{|l|l|l|r|}
\hline \multicolumn{3}{|l|}{ Intensive and Disintensive Implementation } \\
\hline 3A & Does it need to be applied? & \\
\hline & a & Important & $72.0 \%$ \\
\hline & b & Not too important & $12.0 \%$ \\
\hline & c & No need & $0.0 \%$ \\
\hline & d & Do not know & $16.0 \%$ \\
\hline 3B & Has it been applied? & \\
\hline & a & Yes & $0.0 \%$ \\
\hline & b & Not yet / not & $100.0 \%$ \\
\hline
\end{tabular}

Respondents' aspirations towards environmental monitoring were whether there had been $56 \%$ environmental monitoring from the local government answering it, while the rest answered they did not know and did not yet exist. While the opinions of respondents about environmental pollution mostly answered there, with the type of pollution in the form of loss of rocks and sand and river pollution. As for involvement in monitoring if there are pollution and environmental problems the respondents will be directly involved $(56 \%)$ and report (34\%) the rest are not involved.

Table 6. Environmental Monitoring

\begin{tabular}{|c|c|c|}
\hline Enviro & mental Monitorin & \\
\hline 4A. $\mathrm{Hc}_{\mathrm{c}}$ & there been monit & \\
\hline $\mathrm{a}$ & Yes & $56.0 \%$ \\
\hline $\mathrm{b}$ & Not yet / not & $24.0 \%$ \\
\hline $\mathrm{c}$ & Do not know & $20.0 \%$ \\
\hline $\begin{array}{l}\text { 4B. Is } \\
\text { enviro }\end{array}$ & $\begin{array}{l}\text { ere environmenta } \\
\text { nent? }\end{array}$ & \\
\hline $\mathrm{a}$ & Yes & $80.0 \%$ \\
\hline $\mathrm{b}$ & There is no & $20.0 \%$ \\
\hline 4C. W & at pollution is the & \\
\hline $\mathrm{a}$ & Rocks and sand & $37.9 \%$ \\
\hline $\mathrm{b}$ & River & $31.0 \%$ \\
\hline
\end{tabular}

\footnotetext{
*Corresponding author: indraya_kus@yahoo.co.id
} 


\begin{tabular}{|r|l|l|r|}
\hline & c & Soil & $6.9 \%$ \\
\hline & d & Water & $10,3 \%$ \\
\hline & e & There is no & $13.8 \%$ \\
\hline \multicolumn{2}{|c|}{ 4D. Is community involvement in environmental monitoring } \\
\hline & a & directly involved & $56.5 \%$ \\
\hline & b & involved in reporting & $34.8 \%$ \\
\hline & c & not involved & $8.7 \%$ \\
\hline
\end{tabular}

Environmental awareness indicators include obtaining information on whether there are concrete actions by the regional government on environmental issues at KCAGK, most of them have already known of actions $(76 \%)$. The actions taken by the community if they are aware of the existence of environmental problems in the field are direct reprimand, especially carried out by community leaders (48\%) while $48 \%$ will report to the village, LIPI or local community leaders.

Next is the involvement of local communities in protecting the environment, all respondents answered with activities such as voluntary work (84\%), improving the environment (13\%) and making local rules on environmental issues.

Table 7. Environmental Concern

\begin{tabular}{|c|c|c|}
\hline \multicolumn{3}{|c|}{ Environmental Concern } \\
\hline \multicolumn{3}{|c|}{$\begin{array}{l}\text { 5A Are there actions taken due to existing environmental } \\
\text { pollution? }\end{array}$} \\
\hline $\mathrm{a}$ & There is & $76.0 \%$ \\
\hline $\mathrm{b}$ & There is no & $16.0 \%$ \\
\hline $\mathrm{c}$ & Do not know & $8.0 \%$ \\
\hline
\end{tabular}

$5 \mathrm{~B}$ If there are environmental problems encountered in the field, what are your actions?

\begin{tabular}{|r|l|l|r|}
\hline & $\mathrm{a}$ & Direct warning & $48.0 \%$ \\
\hline & $\mathrm{b}$ & Report to the leadership & $44.0 \%$ \\
\hline & $\mathrm{c}$ & Ignoring & $8.0 \%$ \\
\hline $\begin{array}{l}\text { 5C Are there forms or roles in maintaining your } \\
\text { environment }\end{array}$ \\
\hline & $\mathrm{a}$ & There is & $100.0 \%$ \\
\hline & $\mathrm{b}$ & There is no & $0.0 \%$ \\
\hline 5D Role in maintaining the surrounding environment? \\
\hline & $\mathrm{a}$ & voluntary work & $82.8 \%$ \\
\hline & $\mathrm{b}$ & Make local rules & $3.4 \%$ \\
\hline & $\mathrm{c}$ & Improve environmental damage & $13.8 \%$ \\
\hline
\end{tabular}

\subsubsection{Institutional}

\section{A. LIPI (Indonesian Institute of Science)}

\section{A.1. Understanding and Dissemination RTRW}

As a manager at KCAGK for the functions of education and conservation. The respondents' understanding of the spatial planning policy of the Spatial Plan all understood. While for policy dissemination activities, not all understand. For socialization initiatives carried out by LIPI, most of them are direct to the community (including students). The LIPI respondent believes that it is still not fully good at disseminating the RTRW regulations on KCAGK.
Table 8. Understanding and socialization of the RTRW

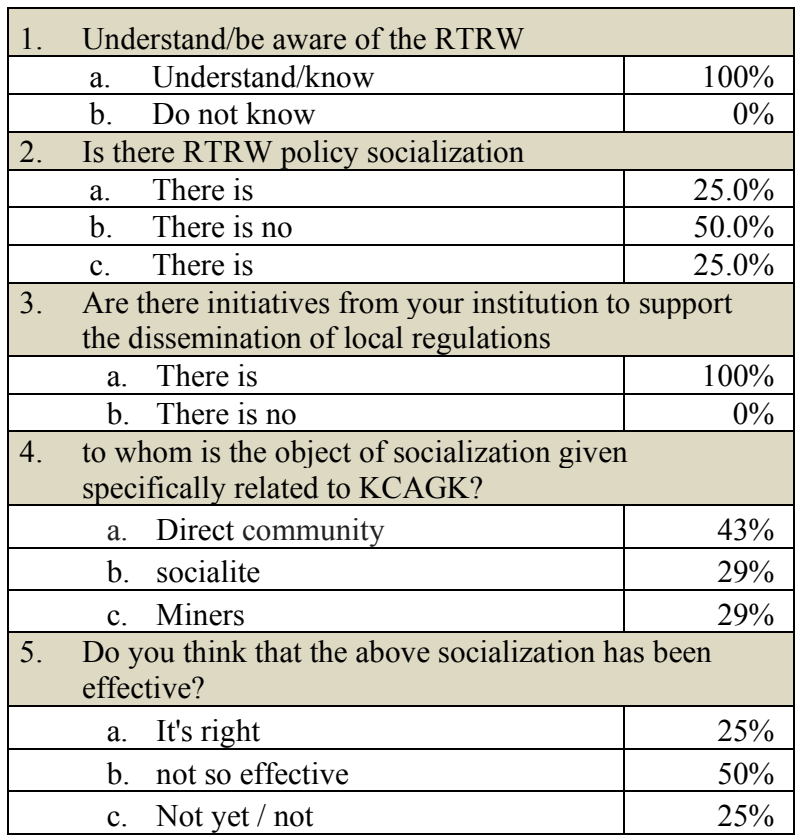

\section{A.2. Mining licensing}

LIPI respondents' opinions on mining licenses at KCAGK include what causes unlicensed miners, the majority are worried that they will not be allowed (50\%) and feel they do not need to be mined on their land despite being geodiversity (25\%). Most of the miners' violations other than no permits are mining techniques that are not environmentally friendly and encroach on protected locations $(40 \%)$. Internally LIPI's role in licensing is in the form of directives and recommendations.

Table 9. Mining licensing

\begin{tabular}{|c|c|}
\hline \multicolumn{2}{|l|}{ 1. Why are miners not licensed? } \\
\hline a. There is no budget & $0 \%$ \\
\hline b. Worry is not allowed & $50 \%$ \\
\hline c. Difficult process & $25 \%$ \\
\hline d. Do not know & $0 \%$ \\
\hline e. Feel unnecessary & $25 \%$ \\
\hline \multicolumn{2}{|c|}{$\begin{array}{l}\text { 2. What violations have been carried out by miners other } \\
\text { than licensing? }\end{array}$} \\
\hline a. Limits of mining areas & $40 \%$ \\
\hline b. Mining technique is not correct & $40 \%$ \\
\hline c. Mining Geodiversity & $20 \%$ \\
\hline d. do not know & $0 \%$ \\
\hline \multicolumn{2}{|c|}{$\begin{array}{l}\text { 3. what is the involvement of your institution in the } \\
\text { implementation of licensing? }\end{array}$} \\
\hline a. Referrals and recommendations & $100 \%$ \\
\hline b. Monitor & $0 \%$ \\
\hline c. There is no & $0 \%$ \\
\hline
\end{tabular}

\section{A.3. Intensive and Disintensive Giving}

The views of LIPI respondents towards the need for intensive and disintensive and have not been implemented so far $(75 \%)$. 
Table 10. Intensive and Disintensive Implementation

\begin{tabular}{|rl|r|}
\hline 1. & Does it need to be applied? \\
\hline a. & Yes, Important & $0 \%$ \\
\hline b. & Not Important & $100 \%$ \\
\hline 2. & Has it been applied? & \\
\hline a. & It is already done & $0 \%$ \\
\hline b. & Half done & $0 \%$ \\
\hline c. & Not yet & $75 \%$ \\
\hline d. & do not know & $25 \%$ \\
\hline
\end{tabular}

\section{A.4. Environmental Monitoring}

The involvement of LIPI in environmental monitoring is directly involved (60\%), reporting $(20 \%)$ and conducting environmental research $(20 \%)$. The existence of staff involved in monitoring $75 \%$ answered there. The involvement of other institutions in environmental monitoring at KCAGK is evenly distributed between LIPI, provincial and district governments. Environmental problems in the form of rocks and sand $(50 \%)$. While the opinions of LIPI respondents with mining still exist because there are no other jobs (60\%).

Table 11. Environmental Monitoring

\begin{tabular}{|l|l|}
\hline 1. What is done by your institution in environmental \\
monitoring at KCAGK & $60 \%$ \\
\hline a. Directly involved & $20 \%$ \\
\hline b. Provide periodic reports & $20 \%$ \\
\hline c. $\quad \begin{array}{l}\text { Conduct research related to } \\
\text { environmental change }\end{array}$ &
\end{tabular}

2. Do you have special staff to monitor the environment at KCAGK

\begin{tabular}{|c|c|}
\hline a. $\quad$ There is & $75 \%$ \\
\hline b. $\quad$ There is no & $25 \%$ \\
\hline
\end{tabular}

3. So far, who is involved in environmental monitoring at KCAGK?

\begin{tabular}{|c|c|c|}
\hline & Internal LIPI & $29 \%$ \\
\hline b. & Regency Agency / OPD & $43 \%$ \\
\hline c. & Provincial Agency / OPD & $29 \%$ \\
\hline & The other & $0 \%$ \\
\hline
\end{tabular}

4. What pollution / environmental problems are there in your environment?

\begin{tabular}{|c|c|c|}
\hline a. & Rocks and sand & $50 \%$ \\
\hline b. & River & $25 \%$ \\
\hline c. & Soil & $13 \%$ \\
\hline & Water & $13 \%$ \\
\hline e. & There is no & $0 \%$ \\
\hline \multicolumn{3}{|c|}{ Why do you think there is still mining at KCAGK? } \\
\hline a. & Good Income & $0 \%$ \\
\hline b. & It is common & $40 \%$ \\
\hline c. & There are no other jobs & $60 \%$ \\
\hline
\end{tabular}

\section{A.5. Financing}

So far, financing has been through routine budget allocations (75\%) and some have answered there is no specific location $(25 \%)$.

Table 12. Financing

In the environmental supervision activities in your agency, where are the sources of funding? a. Allocation of routine budget

\begin{tabular}{|c|c|c|}
\hline & Private assistance fund & $0 \%$ \\
\hline & personal & $0 \%$ \\
\hline & There is no allocational & $25 \%$ \\
\hline
\end{tabular}

\section{A.6. Recommendations for overseeing RTRW policies at KCAGK}

Recommendations related to environmental monitoring of the RTRW Policy are to improve institutional synergy $(40 \%)$, then $20 \%$ want the allocation of funds, the remainder is multiply socialization, involvement of local government and private roles.

Table 13. Recommendations for overseeing RTRW policies

\begin{tabular}{|c|c|}
\hline a. Increase socialization & $10.0 \%$ \\
\hline b. Strengthen supervision from the community & $10.0 \%$ \\
\hline $\begin{array}{l}\text { c. There is an allocation of funds under } \\
\text { supervision }\end{array}$ & $20.0 \%$ \\
\hline $\begin{array}{l}\text { d. Local governments are directly involved in } \\
\text { supervision }\end{array}$ & $10.0 \%$ \\
\hline e. Law enforcement & $0.0 \%$ \\
\hline f. Increasing the role of CSR & $10.0 \%$ \\
\hline g. Institutional synergy & $40.0 \%$ \\
\hline
\end{tabular}

\section{B. $O P D / B K P R D$}

\section{B.1. Understanding and Dissemination RTRW}

Overall, understanding the RTRW policy and socialization activities already exists, but implementation is still not optimal.

Table 14. Understanding and socialization of the RTRW

\begin{tabular}{|c|c|c|}
\hline \multicolumn{3}{|c|}{ 1. Understand/be aware of the RTRW } \\
\hline a & Understand/know & $100 \%$ \\
\hline $\mathrm{b}$ & Do not know & $0 \%$ \\
\hline \multicolumn{3}{|c|}{ What form of socialization was carried out? } \\
\hline a & Meetings/FGDs & $80 \%$ \\
\hline & Media Advertising & $0 \%$ \\
\hline & Social media (IT / era 4.0) & $0 \%$ \\
\hline & Directly to actors in the field & $20 \%$ \\
\hline \multicolumn{3}{|c|}{$\begin{array}{l}\text { 3. Do you think that the above socialization has been } \\
\text { effective? }\end{array}$} \\
\hline & It's right & $25 \%$ \\
\hline & not so effective & $75 \%$ \\
\hline & Not yet / not & $0 \%$ \\
\hline
\end{tabular}

\section{B.2. Mining licensing}

Respondents' perception of illegal miners is that concern is not allowed (40\%) and there is no funds (40\%), while the rest is a difficult process. Associated with violations of illegal miners is mining technically not environmentally friendly $(60 \%)$. While the role of OPD in licensing is direction and recommendations $(100 \%)$.

Table 15. Mining licensing

\begin{tabular}{|r|r|}
\hline 1. Why are miners not licensed? \\
\hline a. There is no budget & $40 \%$ \\
\hline b. Worry is not allowed & $40 \%$ \\
\hline c. Difficult process & $20 \%$ \\
\hline d. Do not know & $0 \%$ \\
\hline e. Feel unnecessary & $0 \%$ \\
\hline
\end{tabular}




\begin{tabular}{|l|r|}
\hline 2. What violations have been carried out by miners \\
other than licensing?
\end{tabular}

\section{B.3. Intensive and Disintensive Giving}

The importance of intensive and disintensive is the answer of all respondents, but the application of most answers does not yet exist (75\%).

Table 16. Intensive and Disintensive Implementation

\begin{tabular}{|r|r|}
\hline 1. Does it need to be applied? \\
\hline a. Yes, Important & $100 \%$ \\
\hline b. Not Important & $0 \%$ \\
\hline c. No need & $0 \%$ \\
\hline d. Do not know & $0 \%$ \\
\hline 2. Has it been applied? & $25 \%$ \\
\hline \multicolumn{2}{|c|}{ a. It is already done } \\
\hline b. Not yet & $75 \%$ \\
\hline
\end{tabular}

\section{B.4. Environmental Monitoring}

OPD involvement $40 \%$ answered that they were not involved, gave reports of $40 \%$ and only $20 \%$ were directly involved. All respondents answered that they did not have human resources under supervision. In the supervision of involvement in KCAGK, the answer was carried out by the provincial government (44\%), the rest were LIPI and the regional government. Most of the environmental problems that occur in KCAGK answer rock and sand pollution (50\%). Whereas the perception of OPD related to the existence of mining is that there are no other jobs.

\section{Table 17. Environmental Monitoring}

\begin{tabular}{|c|r|}
\hline 1. What is done by your institution in environmental \\
monitoring at KCAGK?
\end{tabular}

\begin{tabular}{|c|c|}
\hline c. $\quad$ Soil & $0 \%$ \\
\hline d. Water & $17 \%$ \\
\hline There is no & $17 \%$ \\
\hline \multicolumn{2}{|c|}{ 5. Why do you think there is still mining at KCAGK? } \\
\hline a. Good Income & $0 \%$ \\
\hline b. It is common & $33 \%$ \\
\hline c. There are no other jobs & $67 \%$ \\
\hline
\end{tabular}

\section{B.5. Financing}

Indicators of financing respondents answered there were routine allocations $(50 \%)$ and no allocations (50\%).

Table 18. Financing

\begin{tabular}{|c|r|}
\hline \multicolumn{2}{|l|}{$\begin{array}{l}\text { In the environmental supervision activities in your } \\
\text { agency, where are the sources of funding? }\end{array}$} \\
\hline a. Alokasi dari anggaran rutin & $50 \%$ \\
\hline b. Private assistance fund & $0 \%$ \\
\hline c. Personal & $0 \%$ \\
\hline d. There is no allocational & $50 \%$ \\
\hline
\end{tabular}

\section{B.6. Recommendations for overseeing RTRW policies at KCAGK}

Advice from OPD respondents related to environmental monitoring at the RTRW's policy, most of them want adequate funding (36\%), the role of local communities needs to be strengthened in supervision $(27 \%)$, and the existence of institutional synergy $(27 \%)$.

Table 19. Recommendations for overseeing RTRW policies

\begin{tabular}{|c|c|}
\hline a. Increase socialization & $9.1 \%$ \\
\hline b. Strengthen supervision from the community & $27.3 \%$ \\
\hline $\begin{array}{l}\text { c. There is an allocation of funds under } \\
\text { supervision }\end{array}$ & $36.4 \%$ \\
\hline $\begin{array}{l}\text { d. Local governments are directly involved in } \\
\text { supervision }\end{array}$ & $0.0 \%$ \\
\hline e. Law enforcement & $0.0 \%$ \\
\hline f. Increasing the role of CSR & $0.0 \%$ \\
\hline g. Institutional synergy & $27.3 \%$ \\
\hline
\end{tabular}

\section{Conclusion}

There is a relationship if it is compared between the public's understanding of the RTRW policy and the respondent's answers in the institution (LIPI and OPD), where the community does not understand the existence of RTRW with socialization that is still not optimal according to institutional respondents' answers.

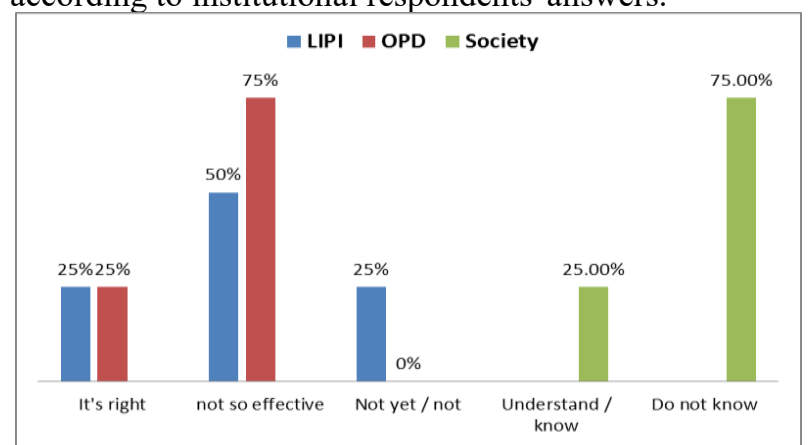

Fig. 2. Graphic relationship if it is compared between the public's understanding of the RTRW policy 
The community's understanding of KCAGK all knows, due to the role of LIPI in KCAGK. In terms of licensing, most miners understand that the activities carried out are illegal because there are no more permits at KCAGK. This condition was strengthened by institutional respondents who chose to worry from miners not allowed. The most violations of illegal miners are mining techniques that are not environmentally friendly.

All respondents on average feel the importance of being intensive and disintensive, but there is no application in the field. Involvement of environmental monitoring of community respondents (community leaders) has been carried out and the desire to be involved in maintaining the environment at KCAGK. Problems arise because they have no place/place specifically in environmental supervision, the absence of funds is an obstacle. While the supervision carried out by the OPD through BKPRD did not work, because the establishment of this institution based on the organizational structure in its implementation on duty was a person who understood the substance.

\section{Recommendation}

1) As a follow-up, this study informs that in the implementation of spatial planning during this stage the supervision is less priority.

2) Opportunities through community leaders can be in the form of a forum to protect the environment, including the supervision of protected areas as strategic areas according to the RTRW.

3) The role of BKPRD needs to be reviewed again, both as a function and as an institutional formation.

4) The allocation of funding needs to be increased and institutional synergy improved between LIPI and OPD (district and provincial governments) in KCAGK supervision activities.

5) With the weak RTRW policy socialization, it is necessary to immediately change the policy supervision approach, namely by implementing an IT-based monitoring system. Industry application 4.0 is expected to be able to answer the lack of human resources, supervision costs.

6) Academically this research can be continued by looking at how they form and container of the community in the supervision of the protected area on the RTRW.

\section{References}

1. N. Tejedor-Flores, P. Galindo-Villardón, P. Vicente-Galindo, Sustainability Multivariate Analysis Based On The Global Reporting Initiative (GRI) Framework Using As A Case Study: Brazil Compared to Spain and Portugal, International Journal of Sustainable Development and Planning 12 (4), 667-677 (2017)

2. B.R. Keeble, The Brundtland Report: "Our Common Future, Medicine and War 4(1), 17-25 (1988)
3. A.V.D. Dunk, A. Grêt-Regamey, T. Dalang, A.M. Hersperger, Defining A Typology of Peri- Urban Land-Use Conflicts - A Case Study from Switzerland, Landscape and Urban Planning 101(2), 149-156 (2011)

4. Arba, The Law on Spatial Planning and Land Use, Sinar Grafika Jakarta (2017)

5. S. Segura, B. Pedregal, Monitoring and Evaluation Framework for Spatial Plans: A Spanish Case Study, Sustainability 9(10) (2017)

6. R.R. Tjandrawinata, Industrial Age 4.0 : Challenges and Opportunities for the Development of Indonesian Vocational Education, Open Session of the Senate Makassar University (2018)

7. R. Wirosoedarmo, J.B.R. Widiatmoko, Y. Widyoseno, Regional Spatial Planning (RTRW) Based on Carrying Capacity of Land-Based Environment, Jurnal Agritech 34(4), 463 (2014)

8. A. Mascarenhas, T.B. Ramos, L. Nunes, Developing An Integrated Approach for the Strategic Monitoring of Regional Spatial Plans, Land Use Policy 29(3), 641-651 (2012)

9. Government Regulation Number 26 of 2008 concerning National Regional Spatial Planning

10. L.T.O. Cheung, L. Fok, W. Fang, Understanding Geopark Visitors' Preferences and Willingness to Pay for Global Geopark Management and Conservation, Journal of Ecotourism 13(1), 35-51 (2014)

11. N.S.M. Fauzi, A. Misni, Geoheritage Conservation: Indicators Affecting the Condition and Sustainability of Geopark - A Conceptual Review, Procedia - Social and Behavioral Sciences 222, 676-684 (2016)

12. H. Setiawan, Effectiveness of Library Orientation Activities (Explanative Study of the Effectiveness of Library Orientation Activities Towards the Utilization of Services at the Airlangga University Library), Official Website Airlangga University 118 (2014)

13. Makmur, Effectiveness of Supervision Institutional Policy, Bandung: Refika Aditama (2016)

14. L. Aliyatushiyam, Control Survey Control Strategy, 1, 45-58 (2016)

15. Kuncoro, Quantitative Methods, UPP STIM YKPN Yogyakarta (2011) 